\title{
The Historiography of Modern Architecture: Twenty-Five Years Later
}

\author{
By Macarena de la Vega de León*
}

\begin{abstract}
Why reopen Panayotis Tournikiotis' The Historiography of Modern Architecture? What for? There are two basic reasons for which Tournikiotis' study is still a useful research tool after 25 years: first, for the historians he covers, it provides the reader with interesting references for further study; and, second, for the study of history and how it is written. In his last chapter, Tournikiotis tries to point out the lessons offered by his discussion on the histories. He emphasizes repeatedly how each history presents modern architecture and how each one tries to design the architecture of the present or even the future. Does this hold true for historiography as well? Is this book, as a discussion on nine different histories, projecting what historiography should be in the future? What is Tournikiotis' real proposal? The aim of this study is to present how several authors have revisited the history and historiography of modern architecture after Tournikiotis' dissertation (defended in 1988), especially after its publication in English in 1999. This essay has two main objectives: first, to reconsider the impact of Tournikiotis' Historiography on further studies of the matter; and, second, to provide a bibliography, as complete as possible. The Historiography of Modern Architecture is a perfect manual for initiating students in the study of the histories of modern architecture. To try to 'complete' it, discussing what has been written since, seems like a small addition to what should be considered as a compulsory starting point for every study of architectural historiography.
\end{abstract}

\section{The Historiography of Modern Architecture: Twenty-five Years Later}

Panayotis Tournikiotis' The Historiography of Modern Architecture is a key study. So it has been described by fellow authors and scholars. ${ }^{1}$ For instance, according to Diane Favro, 'after years with very little self-reflection, architectural history has followed [history, art history and archaeology], producing vital publications exploring the history of the field, methods and research trends. ${ }^{, 2}$ Among those publications is Panayotis' book, published in 1999. However, this book's life started before that year, in 1988 as a doctoral dissertation, as Françoise Choay explains in her foreword. It took more than ten

\footnotetext{
${ }^{*} \mathrm{PhD}$ student at the University of Canberra, Australia and member of the Centre for Creative and Cultural Research.

${ }^{1}$ Tournikiotis, P. (1999). The Historiography of Modern Architecture. Cambridge, Massachusetts: The MIT Press.

${ }^{2}$ Favro, D. (2006). "The digital disciplinary divide: reactions to historical virtual reality models", in Arnold D. (ed.) Rethinking Architectural Historiography. London and New York: Routledge, page 200.
} 
years to turn the manuscript into a book that was published by the Massachusetts Institute of Technology. MIT's editorial work is harshly criticized by Andrew Higgott in his review of The Historiography.

The careful scholarship and innovative thoughts of Tournikiotis' work is not at all well served by MIT's designer. The cover is sombre and decorated with nothing more than a nineteenth-century engraving of a classical mask, while each chapter and sub-section is headed with a spectacularly irrelevant range of similar motifs. The interest of his text has to fight with the book's image, which seems based on a complete misreading, or perhaps ignorance, of the contents of the book. Any new edition should have the benefit of a fresh, appropriate and sympathetic approach to its design. ${ }^{3}$

Figure 1. Cover of Panayotis Tournikiotis' The Historiography of Modern Architecture

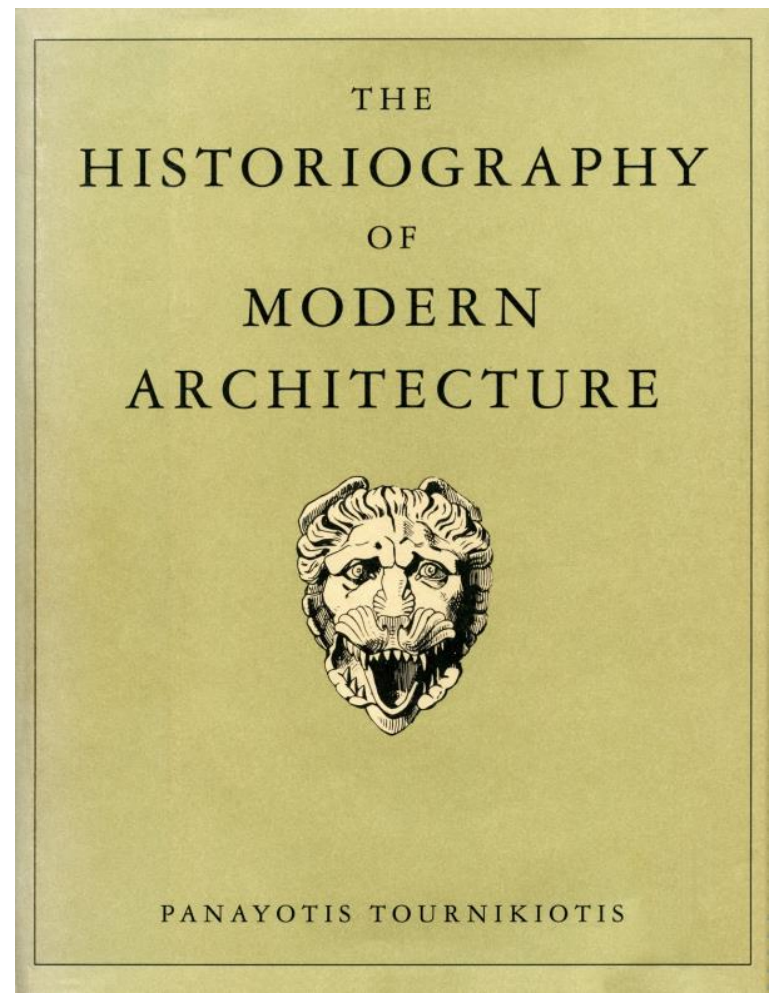

The first Spanish edition appeared in $2001^{4}$ and in the words of Luis Fernández-Galiano it improved not only the graphic project but also the structure of the text' and has more visual clarity and narrative order than the

\footnotetext{
${ }^{3}$ Higgott, A. (2000). Review of The Historiography of Modern Architecture by Panayotis Tournikiotis and Architecture and Modernity: A Critique by Hilde Heynen, AAFiles 41, (summer): page 81.

${ }^{4}$ La historiografía de la arquitectura moderna: Pevsner, Kaufmann, Giedion, Zevi, Benevolo, Hitchcock, Banham, Collins, Tafuri. Madrid: Mairea/Celeste, 2001.
} 
English edition. ${ }^{5}$ In 2002 the book was published in Greek $^{6}$ and the latest evidence of the global influence of The Historiography of Modern Architecture is its availability in Chinese in a translation appeared in 2012. ${ }^{7}$ A new revised and updated Spanish edition was published in $2014 .^{8}$

The aim of this essay is to discuss the impact of The Historiography on recent works in the field. Therefore, the starting point ought to be a discussion of Tournikiotis' contribution to the 'writing of histories' (the name of the last chapter, which could be understood as an extended conclusion) to help determine the true reasons for this book's relevance. Moreover, the study of the influence that it has had on a selection of works would bring more arguments into discussion. These selected works are Anthony Vidler's Histories of the Immediate Present: Inventing Architectural Modernism, Gevork Hartoonian's The Mental Life of the Architectural Historian: Re-opening the Early Historiography of Modern Architecture and Trevor Garnham's Architecture Re-assembled: the Use (and Abuse) of History.

But first, a brief commentary should be made on Tournikiotis' conclusions. One of his key concepts is genealogy, understood as the group of chosen pioneering architects whose work led to the Modern Movement according to each historian. The author states clearly that the choice of genealogy shows each historian coming to a decision and that the way in which historians present it gives a certain character, démarche, to their discourses: operative, derogative, veridical or interrogative. Can these categories be used to discuss other histories? Tournikiotis insists on the relevance of genealogy as it can be used to 'lay foundations', to 'refound', to 'dismantle meanings', to 'introduce new terms' and to 'open new horizons'.

According to Tournikiotis, at the time when he was writing The Historiography it made no sense to return to genealogies and histories such as those being discussed in his book. What the author did find necessary was 'the formulation of a different discourse about the recent past of contemporary architecture'. 10

Based on ideas from Martin Heidegger, Henri-Irénée, Leopold von Ranke or Michel de Certeaus, Tournikiotis makes a proposal: an idea of history as the relationship between past and present that depends on each historian's conception of reality. Even though such a history could not be considered 'objective', a true value can be appreciated in it. Each historian narrates that relationship past-present conditioned by the theories on which he constructs his discourse and by his view of the past. Thus, it can be affirmed that for Tournikiotis reality disappears and what remains are narratives.

Reading this book and the way in which Tournikiotis presents and dismantles each discourse, reveals how 'history' and 'theory' are confused in

\footnotetext{
${ }^{5}$ Fernández-Galiano, L. (2002). "Para hacer las paces con el pasado". Arquitectura Viva volume 14 no. 82, (January-February), page 89.

${ }^{6}$ Athens: Ekdoseis Alexandreia, 2002.

${ }^{7}$ Beijing: Tschinghua University Press, 2012.

${ }^{8}$ Barcelona: Reverté, 2014.

${ }^{9}$ Tournikiotis, P. (1999). The Historiography..., page 231.

${ }^{10}$ Ibid., page 232.
} 
the histories of modern architecture, the latter being more prescriptive than descriptive. This is the reason why the author approves of Manfredo Tafuri's engagement: histories of modern architecture are "true architectural projects'. ${ }^{11}$ Reflecting on this question leads Tournikiotis to ask himself about the aim of the making of history; the answer in each case takes him without exception to Leon Battista Alberti's principles: necessitas, commoditas and voluptas (necessity, commodity and delight). In every historian of his corpus, despite their differences, the author perceives an intended 'reintegration of necessity, convenience, and delight in the early twentieth century', defining the special nature of modern architecture. ${ }^{12}$

Tournikiotis keeps in mind that the first historians of modern architecture were art historians, who focused their attention on appearance and visual perception, on aesthetics. Reintegration somehow becomes the perfect excuse for the lesser importance historians gave to function and construction. In the end, every historian in Tournikiotis' corpus based their narratives on those first histories, some to confirm them, others to reject or even oppose them. Every historian bases his text, one way or another, on the same histories used in the nineteenth century, in order to make a proposal: 'a repertoire of the knowledge necessary for the process of conceiving in the present and the future, for the process of the architectural project'. ${ }^{13}$ As a result, despite the difference between the object, intentions and aims of the history of art and the history of architecture, Tournikiotis states that the former lays the foundations of the latter.

He continues reflecting on the difference between past, present and future, and how they are presented in the discourses which form his corpus. Tournikiotis understands 'identity' as a concept used by historians prior to the 1960s to create direct links with certain projects of the past. In the following years 'identity' was replaced by the concept of 'difference', which was used to define modern architecture, to study its structure and, thus, to transcend it in the direction of a truly new architecture. Tournikiotis based this idea of difference in conceiving the past on two prestigious discourses: on the one hand, Rudolf Wittkower's Architectural Principles in the Age of Humanism $^{14}$, where he discusses a series of principles applied in the procedure of the architectural project of the present (the 'subjective' approach); and on the other hand, Erwin Panofsky's "Der Begriff des Kunstwollens" conceives a 'scientific' system that distances itself from the past searching for objectivity and impartiality, and proposing a different and indifferent perception of the past (the 'objective' approach). Both standpoints allow Tournikiotis to distinguish between a modern concept of history, which looks at the past with present eyes, and a metamodern concept of history, which

\footnotetext{
${ }^{11}$ Tournikiotis, P. (1999). The Historiography..., page 238.

${ }^{12}$ Ibid., page 243.

${ }^{13}$ Ibid., page 247.

${ }^{14}$ Wittkower, R. (1949). Architectural Principles in the Age of Humanism. Londres: Warburg Institute.

${ }^{15}$ Panofsky, E. (1920) "Der Begriff des Kunstwollens”, Zeitschrift für Ästhetik und Allgemeine Kunstwissenschaft 14.
} 
distances itself from the past in order to, ultimately, make peace with it. In his review of the first Spanish edition, Fernández-Galiano regards Tournikiotis' Historiography as 'a necessary aid to "make peace with the past". ${ }^{16}$ John Peponis also refers to this idea of the importance of making peace with the past, and adds that it is a phrase borrowed from Rykwert and that can even be applied to Tournikiotis himself.

Tournikiotis operates rather like a sophisticated theoretical cartographer. A major strength of his remarkable book is that it forces us to take a close look at the texts while at the same time requiring us to remain disengaged from the contested positions that are being investigated. As a scholar who looks at recent modes of history and theory he seems to have made his 'peace with the past'. ${ }^{17}$

To conclude, once again Tournikiotis leans on several historians and theoreticians such as Hubert Damisch, Karl Löwith, Georg G. Iggers, Nikolaus Pevsner and Karl Popper, to reflect on the concept of historicism, and he comes to the conclusion that these historians (from Emil Kaufmann to Manfredo Tafuri) are 'working on the same level'; that 'the discourse they articulated stood at the same distance from the discourse that had been articulated in the nineteenth century'. ${ }^{18}$ They discuss a modern architecture of the present, aware of its historicity and critical towards the past, a past that should be studied and applied to an architectural project that looks forward in the direction of the future. In spite of the differences in genealogy and aims between each narrative, a significant conclusion after reading The Historiography is that Tournikiotis considers all these texts to 'lie on the same level'. ${ }^{19}$

The present study continues with the examination of what could be considered the historiographies written in the twenty-first century: three books in which the influence of Tournikiotis' Historiography will be discussed.

\section{Re-Inventing Architectural Modernism}

We will start with Anthony Vidler and his Histories of the Immediate Present. ${ }^{20}$ Vidler discusses four categories and four historians who embodied the re-invention of architectural modernism: Neoclassical Modernism through Emil Kaufmann; Mannerist Modernism through Colin Rowe (the only not included in Tournikiotis' corpus); Futurist Modernism through Reyner Banham; and Renaissance Modernism through Manfredo Tafuri. Vidler, like

\footnotetext{
${ }^{16}$ Fernández-Galiano, L. (2002). "Para hacer las paces...”. page 89.

${ }^{17}$ Peponis, J. (2001). Book reviews, The Journal of Architecture, volume 6 no.1, page 102. DOI: $10.1080 / 136023600010024831$.

${ }^{18}$ Tournikiotis, P. (1999). The Historiography..., page 266.

${ }^{19}$ Ibid., page 268.

${ }^{20}$ Vidler, A. (2011). Histories of the Immediate Present: Inventing Architectural Modernism. Cambridge, Massachusetts: The MIT Press.
} 
Tournikiotis, offers the reader a thorough and complete examination of the chosen historians. Moreover, he ends up reflecting on history -or, in this case, on post-histoire - a discourse that needs to be read carefully in order to search for the influence of Tournikiotis' Historiography (if any).

Figure 2. Cover of Anthony Vidler's Histories of the Immediate Present: Inventing Architectural Modernism

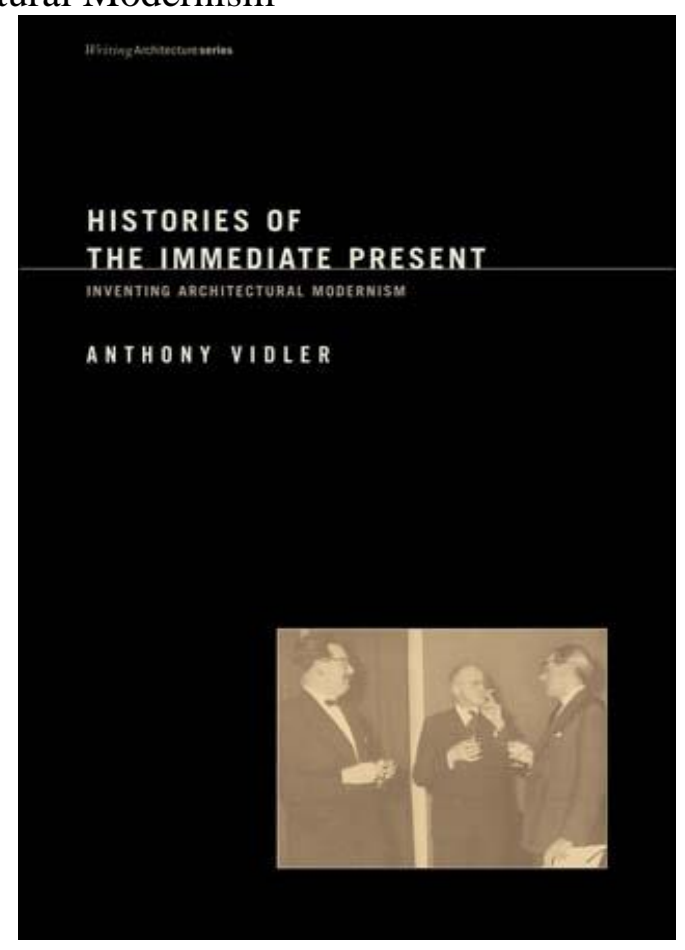

Vidler uses Tournikiotis to comment on 'the first scholarly examinations of modern architecture [that] began to appear in the late 1920s': those written by Adolf Behne, Gustav Adolf Platz, Sigfried Giedion and Henry-Russell Hitchcock. ${ }^{21}$ According to Vidler, Tournikiotis' book showed that 'these narratives shared a common concept of history as a determining, unfolding force, capable of articulating questions of the past, present, and future of architecture, as well as a belief in some form of sociocultural zeitgeist that, if correctly identified, equally determines the respective "modernity" or nonmodernity of the work'. ${ }^{22}$ In the note accompanying this commentary, Vidler both praises and criticises The Historiography: on the one hand, it is an 'excellent analysis' and 'must form the basis of any serious study of the works' of every historian of his corpus; on the other hand, he comments on the 'structuralist' character of Tournikiotis' approach and on the lack of context. ${ }^{23}$ It is precisely this lack of context that is the main difference between both works, according to Vidler:

\footnotetext{
${ }^{21}$ Vidler, A. (2011). Histories of the Immediate..., pages 5-6.

${ }^{22}$ Ibid., page 6 .

${ }^{23}$ Ibid., page 201 , footnote 4 .
} 
The present work, however, studies these relations specifically, understanding the writing of history, whether or not under the guise of objectivity, to form a practice immersed in the theory and design of architecture at any one moment, within a comprehensive practice that, as it embraces all aspects of the architectural field, might properly be called its 'discourse'. ${ }^{24}$

As a result of reading Vidler's reflection on the concept of post-histoire, it could be inferred that the author follows none of the paths opened by Tournikiotis. Was it still necessary to dismantle the misinterpreted relationship between modernism and history? Despite the theme discussed, Vidler doesn't use Tournikiotis' categories ('identity' and 'difference') nor does he explore the way modern architecture related to the past; all the ideas presented in The Historiography's last chapter. Therefore, Vidler's conclusion would be that modernism must be called into question, one of the tasks that architectural history has to face in the future:

We would need to reassess disruptive moments and figures, not as curiosities or embarrassments, nor as washed-up utopias (utopia, after all, is a posthistoire concept), but as openings into the process, rather than the appearance, of modernity; we would also need to seriously reevaluate the sacred cows of modernity, whose work has become, too quickly, canonical, in order to detect the internal inconsistencies, the still-open questions lurking behind their monographical facades; finally, we would need to open those ideas of "modernism" so prevalent after the Second World War that were proposed in order to tidy up the erratic field of the early avant-gardes and to provide rules for being modern in the era of reconstruction. ${ }^{25}$

Was not this clear enough in 1999 when Tournikiotis' Historiography was published? It seems that Vidler's study of four historians has not led him beyond modernism; nor has it led him towards a profound reflection on history. However, Alan Powers has argued that Vidler's work is, in fact, a 'useful contribution to the body of literature in this field. It is a short book, focused on only four writers, and as such it may be more accessible to students than other more panoptic works, such as Panayotis Tournikiotis' The Historiography of Modern Architecture. ${ }^{26}$ Andrew Leach used the term 'usefulness', again used to refer to Vidler's work regarding the possibilities of a direct relationship between history and theory. ${ }^{27}$

\footnotetext{
${ }^{24}$ Vidler, A. (2011). Histories of the Immediate..., page 201.

${ }^{25}$ Ibid., pages 199-200.

${ }^{26}$ Powers, A. (2001). Review of Histories of the Immediate Present: Inventing Architectural Modernism by Anthony Vidler. Times Higher Education. 17 of July.

${ }^{27}$ Leach, A. (2010). What is Architectural History. Cambridge, UK and Malden, MA.; Polity Press, page 119.
} 


\section{Re-opening the Early Historiography}

The next book of interest was published in 2011: The Mental Life of the Architectural Historian, written by Gevork Hartoonian. ${ }^{28}$ This work follows the tendency to study fewer historians (as seen above in Vidler's work), which in Hartoonian's case are the three authors responsible for early histories of modern architecture: Nikolaus Pevsner, Henry-Russell Hitchcock and Sigfried Giedion. Hartoonian intends to examine the true nature of these histories with two aims: first, to highlight connections and differences between the history of architecture and the tradition of the history of art; and second, to establish analytical categories for these first histories 'to sharpen the profile of a historical time that has been formative for a contemporary understand of the project of modernity'. ${ }^{29}$ As did Vidler, Hartoonian takes the context into account and explores his historians' mental life combining three different aspects: the influence that previous historians had on their work, the links to contemporary theory of art and architecture, and the reading that Kenneth Frampton or Manfredo Tafuri have made of their ideas and concepts.

Figure 3. Cover of Gevork Hartoonians's The Mental Life of the Architectural Historian: Re-opening the Early Historiography of Modern Architecture

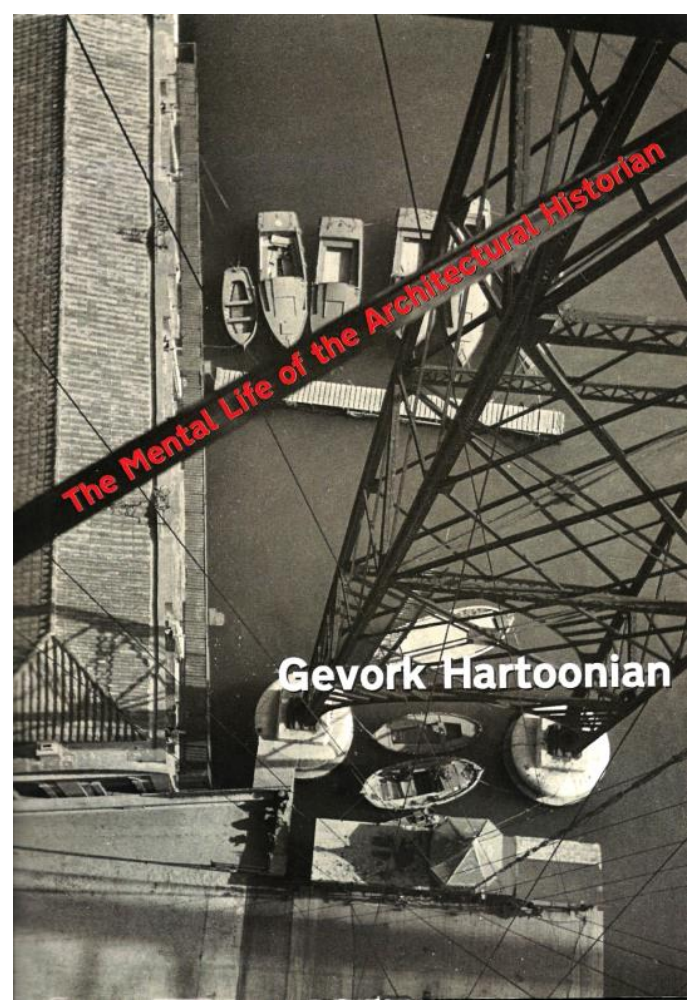

\footnotetext{
${ }^{28}$ Hartoonian, G. (2011). The Mental Life of Architectural Historian: Re-opening the Early Historiography of Modern Architecture. Newcastle upon Tyne: Cambridge Scholars Publishing.

${ }^{29}$ Ibid., page 1 .
} 
Tournikiotis forms part of the basis of Hartoonian's discourse; he embodies a way of understanding history, that was launched with Hegel and "landed in "an historical conjunction" where history is ossified in "documents" and "events". According to Hartoonian, Tournikiotis 'is the first one' -and it should be added 'the last'- 'to take into consideration the entire gamut of contemporary historiography of architecture'. ${ }^{30}$

Foregrounding the importance structuralism gives to the discursive formation, Tournikiotis explores historical narratives, highlighting the way each attempts to map architecture at different moments in history. Both architects and their work recede in his historiography except when the work is of the capacity to structure the historian's narrative. Gone with the author (historian) is the latter's reconstruction of the past towards a defined end(s). What informs Tournikiotis' narrative is the autonomy of text. His book, however, is a major feat in re-writing architectural history from a structuralist position. $^{31}$

Hartoonian's selected quotes and footnotes help to complete Tournikiotis' bibliography, including even unpublished dissertations and studies. Contrary to Vidler's approach, Hartoonian's examination of early historiography allows him to build a thorough discourse on history and on the relationship between architects and historians. He draws a parallel between the state of history around the 1930s and the critical histories written by Frampton and Tafuri:

If periodization is one subject to be addressed [here], another is the importance given to abstract painting and its mediating role between the spirit of modernism and architecture. A third subject should concern the historian's will to set a date, mark a point in time, and codify aesthetic or technical norms that modern architecture was expected to regard. These three themes will be discussed [here] to demonstrate the parallelism running between the architects' practice and the historians' theorization of modern architecture throughout pre-war historiography. A parallel discussion of historicism is plotted to address the theme of autonomy permeating both architects' and historians' work since the 1960s. The latter would allow us to examine the reception of autonomy in critical historiography popularised by Kenneth Frampton and Manfredo Tafuri. ${ }^{32}$

Hartoonian not only provides the analysis of text with new tools and rereads the pioneer historians; he also comes to interesting and useful conclusions that go beyond modernism. 'What brought together a diverse

\footnotetext{
${ }^{30}$ Hartoonian, G. (2011). The Mental Life..., page 6.

${ }^{31}$ Ibid., pages 6-7.

${ }^{32}$ Ibid., pages 142-143.
} 
group of architects who worked on and recorded their aspirations and utopias of modern times had to do with the analogies these modernists drew between architecture and the spirit of the time. ${ }^{33}$ This was an idea that was true not only for the period between-wars or for 'critical times'; it could also be true today. Thus, Hartoonian reflects on the discipline's future and on the idea of architecture as something global, on a 'semi-autonomous' architecture.

\section{Re-assembling Architecture}

This study ends in 2013, twenty-five years after the reading of Tournikiotis' dissertation, with the release of Architecture Re-assembled: the Use (and Abuse) of History, by Trevor Garnham. ${ }^{34}$ This author aims to reevaluate the past 'looking there actively and creatively for lessons to help forge a living culture, a culture of the present and appropriate to the times'. ${ }^{35}$ In the introduction, Garnham states two main objectives: first, to examine the idea that history is necessary for life; and second, to re-read architecture and its history convinced that the latter is important for the contemporary architectural project.

Figure 4. Cover of Trevor Garnham's Architecture Re-assembled: The Use (and Abuse) of History

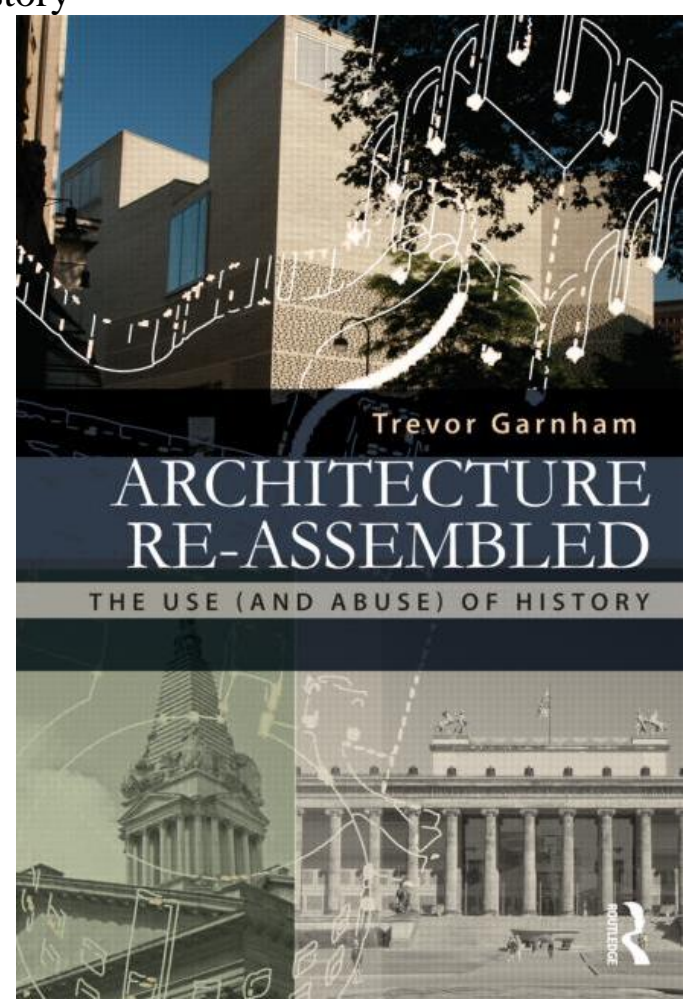

\footnotetext{
${ }^{33}$ Hartoonian, G. (2011). The Mental Life..., page 173.

${ }^{34}$ Garnham, T. (2013). Architecture Re-assembled: the Use (and the Abuse) of History. New York and London: Routledge.

${ }^{35}$ Ibid., page VII.
} 
It may seem surprising that Tournikiotis does not appear until chapter 6, but that is only due to the book's wide thematic range. It is not until chapter 6 that Garnham begins to deal with modernism, and, thus, Tournikiotis begins to appear every time the author refers to a historian treated in The Historiography. This confirms that for Garnham, as well as for Vidler or Hartoonian, the book was a necessary basis. It is so obvious that Garnham supports his discourse on Tournikiotis that, after commenting on Tafuri (the last historian in The Historiography's corpus) he even asserts in the chapter about postmodernism that 'if Tournikiotis had continued his study beyond the 1960s he would almost certainly have led with Charles Jencks as the 'operative' historian of postmodern architecture'. ${ }^{36}$

It may also seem surprising, but there is no sign in Garnham's text showing that he did any critical evaluation of Tournikiotis' work. Moreover, it could be inferred by his commentaries that his reading is superficial and even incorrect. Such an assertion or sensation must be justified with examples. First, when introducing the pioneering historians, Garnham seems to suggest that Tournikiotis accepted the idea that modernism was ahistorical, when he affirms that later studies -without naming them- began to examine modernism's complex relationship with history. Second, something that could seem to be anecdotal: when referring to Hitchcock, Garnham claims that he is one of the pioneering historians in The Historiography. Anyone who has merely looked through the book's contents knows that Tournikiotis places Hitchcock in his own chapter after Bruno Zevi and Leonardo Benevolo and spends part of that chapter justifying his decision.

A superficial character extends all through the text of Architecture Reassembled; it may be due to the enormous number of themes, historians, theoreticians, architects, buildings and movements Garnham deals with. The lack of rigour is also obvious in the bibliography, where there is no reference to original editions, just English translations.

To sum up, Architecture Re-assembled is, according to the author himself, a 'general vision'. At this point, it may not come as a surprise to anyone that the only common categories (common to the wide range of events, times, architects and theoreticians starring in the book) that he can discuss in his conclusion are history, tradition and memory. Once again Garnham leans on several architects and historians to describe these three categories as 'interrelated measures or modes of our understanding of time, and their implications for architecture cannot be ignored'. ${ }^{37}$

\section{[Re- $]$}

There is no doubt that Tournikiotis' manual is the basis, the starting point for any re-assessment of modern architecture. However, to consider the influence of The Historiography on the subsequent studies selected here is not

\footnotetext{
${ }^{36}$ Garnham, T. (2013). Architecture Re-assembled..., page 174.

${ }^{37}$ Ibid., page 195.
} 
an easy task. Therefore, this conclusion intends to reflect, first, on what these three studies have in common and, then, on what distinguishes them, on what may be their true contribution.

The three authors admit (though each with different words) to having based their works, partially or totally, on The Historiography. Even more important than what they say, is what they do, and plenty of references can be found in the three books: Vidler follows the tips given by Tournikiotis when studying his selected historians; Hartoonian discusses the book as one of his starting points in the introduction; and Garnham builds his discourse leaning shamelessly on The Historiography. These so-called 'historiographies of the twenty-first century' suggest two main possible trends in the field, two possible paths to follow: on the one hand, to reflect on the history of architecture as a discipline, discussing methodology, strategies, tools, and applying them to reopen certain periods (in the case of Architecture Re-assembled a wide one); on the other hand, to re-evaluate the work of certain historians and re-write the history of modern architecture (Vidler and Hartoonian).

At the same time, each author made his personal reading of Tournikiotis' proposal, each reaching different levels of depth. Each study shows differences and it is in these differences where their true contribution lies.

From Vidler's Histories the clarity in including the context when discussing the writing of Kaufmann, Rowe, Banham and Tafuri should be highlighted. The book allows a full re-evaluation of the histories by those authors, but its final reflection on history (doubtlessly interesting) has little connection with the historiography of the future proposed by Tournikiotis.

Similarly to Vidler, Hartoonian in The Mental Life of the Architectural Historian -which has the subtitle Re-opening the Early Historiography of Modern Architecture- adds the theoretical and historical context when discussing Pevsner, Hitchcock and Giedion. In this case, the difference can be found in the reflection on history outlined in a way that continues some of Tournikiotis' interesting ideas, for example when Hartoonian examines the relationship between the historian and the architect. He provides the reader with new tools and a re-conceptualization of periodization or autonomy, in order to apply them in re-opening the early histories of modern architecture.

Both Vidler and Hartoonian take into account exactly what Tournikiotis deliberately left aside in his analysis: context. This essay has drawn a circle that in a way ends with Garnham's book (Architecture Re-assembled); a book that intends to include the theoretical and practical context in a discourse that covers more than two centuries. Such a chaotic result could be used to demonstrate how right Tournikiotis' choice was. In The Historiography he focuses only on the histories' context not only because of his structuralist approach, but also because is the only sensible way to deal with such a large number of historians of modern architecture. It is necessary to stress the use of this word, 'historian', since, according to Mark Jarzombek is his review of The Historiography, it is the first book to include historians in the narrative of modern architecture. Something that William Curtis, Kenneth Frampton or even Manfredo Tafuri or Francesco Dal Co failed to do. 'Panayotis 
Tournikiotis' book reminds us that even at this most foundational level historians throughout the twentieth century played critical roles in defining and transforming the priorities of the Modern Movement. ${ }^{38}$

In his review, Peponis used the term 'cartographer' and it can be argued that Tournikiotis' work in The Historiography has an exploratory character. According to Kjtil Fallan, Tournikiotis' contribution to the field of the historiography of architecture is both 'timely' and 'intriguing'. 'His mapping and critique of the long tradition of writing genealogic, projecting deterministic architectural history is important as a potential corrective in the further development of this field of studies.' 39

Twenty-five years later, Panayotis Tournikiotis' The Historiography of Modern Architecture has turned out to be more ambitious and useful than any other contribution to the field. Succeeding works complement it but have no chance of replacing it. The lack of context may be the issue with the greatest impact as it has forced other authors to reconsider historians' mental life taking into account more than just their writings. Another important detail that should be mentioned is the way in which Tournikiotis, as well as Vidler and Hartoonian, force the histories' content so that it fits into their theoretical framework. Every author chooses to study certain historians, to re-read them with an intention that fits their own agendas. It is vital not to forget that those historians were accused of choosing certain architects or buildings due to an intention that fitted their own 'hidden' agendas as well.

To draw a parallel between historians and historiographers is an attractive conclusion that shows that there is still a history of modern architecture to reopen, re-think and re-frame. This is the only way to follow in Tournikiotis footsteps: to re-write it.

\section{Acknowledgements}

My thanks to Jorge Sainz for commissioning this work and publishing this essay as a postscript of the $2^{\text {nd }}$ edition in Spanish of Panayotis Tournikiotis' The Historiography of Modern Architecture. And my special thanks also to Panayotis Tournikiotis for attending this paper's presentation at the ATINER $4^{\text {th }}$ Annual International Conference on Architecture, on July 7, 2014 in Athens.

\footnotetext{
${ }^{38}$ Jarzombek, M. (2001). Review of The Historiography of Modern Architecture by Panayotis Tournikiotis. The Journal of the Society of Architectural Historians, volume 60 no. 1 (March): page 108.

${ }^{39}$ Fallan, K. (2010). Design History: Understanding Theory and Methods. Oxford- New York: Berg, page 126.
} 


\section{References}

Arnold , D. (2002). Reading Architectural History, London and New York: Routledge.

Arnold, D., Altan Ergut, E. \& Tura Özkaya, B (eds.) (2006). Rethinking Architectural Historiography. London \& New York: Routledge.

Ballantyne, A. (2002). What is Architecture? London \& New York: Routledge.

Borden, I. \& Rendell, J. (eds.) (2000). Intersections: Architectural Histories and Critical Theories. London \& New York: Routledge.

Fallan, K. (2010). Design History: Understanding Theory and Methods. Oxford and New York: Berg.

Fernández-Galiano, L. (2002). "Para hacer las paces con el pasado". Arquitectura Viva volume 14 no. 82 (January-February), page 98.

Garnham, T. (2013). Architecture Re-assembled: The Use (and Abuse) of History. London \& New York: Routledge.

Groat, L. \& Wang, D. (2002). Architectural Research Methods. New York: John Wiley \& Sons Inc.

Hartoonian, G. (1997). Modernity and its Other: a Post-script to Contemporary Architecture. Texas: College Station.

Hartoonian, G. (2011). The Mental Life of the Architectural Historian. Re-opening the Early Historiography of Modern Architecture. Newcastle upon Tyne: Cambridge Scholars Publishing.

Higgott, A. (2000) Review of The Historiography of Modern Architecture by Panayotis Tournikiotis and Architecture and Modernity: A Critique by Hilde Heynen, AAFiles 41, pages 80-82.

Jarzombek, M. (2001). Review of The Historiography of Modern Architecture by Panayotis Tournikiotis. The Journal of the Society of Architectural Historians, volume 60 no. 1 (March): pages 107-108.

Jarzombek, M. (2011). The Psychologizing of Modernity: Art, Architecture and History. Cambridge, UK: Cambridge University Press.

Jarzombek, M., Prakash, V. \& Ching, F. (2011). A Global History of Architecture. New Jersey: John Wiley \& Sons.

Kruft, H. (1994). A History of Architectural Theory. New York: Princeton Architectural Press.

Leach, A. (2010). What is Architectural History. Cambridge, UK and Malden, Massachusetts: Polity Press.

Leach, N. (ed.) (1997). Rethinking Architecture: a Reader in Cultural Theory. London and New York: Routledge.

Nesbitt, K. (ed.) (1996). Theorizing a New Agenda for Architecture: 1965-1995. New York: Princeton Architectural Press.

Peponis, J. (2001). Book reviews, The Journal of Architecture, volume 6 no.1, pages 97-105. DOI: $10.1080 / 136023600010024831$.

Powers, A. (2008). Review of Histories of the Immediate Present: Inventing Architectural Modernism by Anthony Vidler, Times Higher Education. 17 of July.

Tournikiotis, P. (1999). The Historiography of Modern Architecture. Cambridge, Massachusetts: The MIT Press.

Vidler, A. (2008). Histories of the Immediate Present: Inventing Architectural Modernism. Cambridge, Massachusetts: The MIT Press. 